\title{
Retinal Ganglion Cells in Strigidae Raptors: Distribution and Morphometry
}

\author{
Células Ganglionares de la Retina en Aves Rapaces Strigidae: Distribución y Morfometría
}

\author{
Alessandra Coli; Maria Rita Stornelli; Carla Lenzi \& Elisabetta Giannessi
}

COLI, A.; STORNELLI, M. R.; LENZI, C. \& GIANNESSI, E. Retinal ganglion cells in strigidae raptors: distribution and morphometry. Int. J. Morphol., 36(4):1175-1179, 2018.

SUMMARY: The authors studied the morphometry and the topographical distribution of Retinal Ganglion Cells (RGCs) in four nocturnal raptors of the order of Strigiformes, family of Strigidae: little owl, tawny owl, scops owl, eared owl. In order to recognize specialized retinal vision areas (fovea and visual streak), the number of RGCs $/ \mathrm{mm}^{2}$ and the soma size in the four retinal fields (dorsal, ventral, temporal and nasal) by the histological analysis of retinal radial sections were recorded. A temporal fovea was identified in little owl, tawny owl and eared owl while in scops owl this visual area was localized near the fundus oculi. A radial visual streak ventrally directed was pointed out in the retinas of the four raptors with different shape according to its width. The Authors linked the obtained data with the predatory behavior of nocturnal raptors in their habitat.

KEY WORDS: Retinal ganglion cells; Morphometry; Topographical distribution; Nocturnal raptors; Strigidae.

\section{INTRODUCTION}

Strigidae are a family of raptors belonging to the order of Strigiformes, which includes over 200 living species and 25 genera. Also defined as "true owls" or "typical owls", they are found world-wide, covering nearly all types of terrestrial habitats. As all the Strigiformes, they have eyes placed frontally and surrounded by feathers arranged in concentric circles, strong hooked beak, feet armed with claws, soft and abundant plumage that extends to cover also the tarsal bones and sometimes the fingers. As well as other raptors, they have a very well developed sense of sight with large elongated eyes and slightly thickened corneas. Large pupils allow an increase of the amount of light that stimulates the photoreceptors. The number of rods in their retina is high, allowing them an increased sense of vision in twilight even if they cannot see in darkness. The eyes are fixed in their orbits by a bony sclerotic ring, therefore they need to turn head to see the surrounding environment. An excellent sense of hearing allows them an increased hunting skills towards prey that cannot be seen. Few studies investigate the differences in eye shape and retinal organization of Strigiformes in relation to their type of predation. Even if they are nocturnal birds, only about $30 \%$ of all species are strictly nocturnal and the other species are from crepuscular or catemerals to diurnal (Gutiérrez-Ibáñez et al., 2013). Moreover, the different activity pattern is linked not only to photoreceptor density and rod/cone ratio, but also to shape and depth of the fovea and number and distribution of Retinal Ganglion Cells (RGCs) (Oehme, 1961). Strigiformes have only a temporal fovea (Jones et al., 2007) which is associated with the frontal position of the eyes and thus improving the binocular vision. At the retinal level, the "visual streak" assumes a radial and symmetrical shape (Lisney et al., 2012; Coli et al., 2018), confirming the observation that many Strigiformes follow prey using the lower part of their visual field, and therefore they do not have the lower-field myopia demonstrated in many other birds.

In the present work we studied the Retinal Ganglion Cells (RGCs) from eyeballs of four Strigidae genera, focusing on the relationship between their topographical retinal distribution and soma size, then comparing the morphometrical data among the four raptors.

\section{MATERIAL AND METHOD}

The retinae were taken from eyeballs of four Strigidae genera: little owl (Athene noctua), tawny owl (Strix aluco), scops owl (Otus scops) and eared owl (Asio otus). All

Department of Veterinary Sciences, University of Pisa,Pisa, Italy. 
specimens came from a center of recovery of birds (Lipu, Livorno, Italy) after systemic diseases or impact trauma. The raptors were euthanized following a certified avian protocol (Embutramide, $0.5-3 \mathrm{mg} / \mathrm{kg}$ intrapulmonary) and the retinal samples were collected by trans conjunctival enucleation. All data were reported from the study of left eyeball. Each sample was cut cranially to ora serrata and fixed in $4 \%$ paraformaldehyde in $0.1 \mathrm{M}$ phosphate buffered saline (PBS, $\mathrm{pH}$ 7.4). After washing several times in PBS, samples were cryoprotected in a solution of $20 \%$ sucrose in PBS, orientated taking the pecten position as reference point, frozen at -80 ${ }^{\circ} \mathrm{C}$ and stored at $-20{ }^{\circ} \mathrm{C}$. Retinal radial serial sections $(10$ $\mu \mathrm{m}$ thick) were obtained by a cryomicrotome (Kryostat 1720 , Leitz Wetzlar) to localize the RGCs, excluding the displaced amacrine cells of the inner plexiform layer. The slices were mounted on gelatin-coated slides and stained with thionine blue at $0.1 \%$ (Nissl method) to highlight Nissl body. For the topographical study, RGCs from dorsal (D), ventral (V), temporal $(\mathrm{T})$ and nasal $(\mathrm{N})$ fields in each section were studied

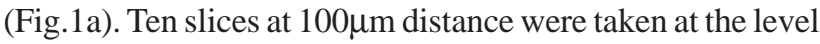
of ora serrata (level 1), at the level the optic disc (level 3) and at the level of intermediate position (level 2) (Fig.1b). RGCs were identified as showing the following cytological features (Duke-Elder, 1958; Cunningham, 2006):

- Polygonal cell body

- Nissl body in the cytoplasm

- Euchromatic oval nucleus and round nucleolus.

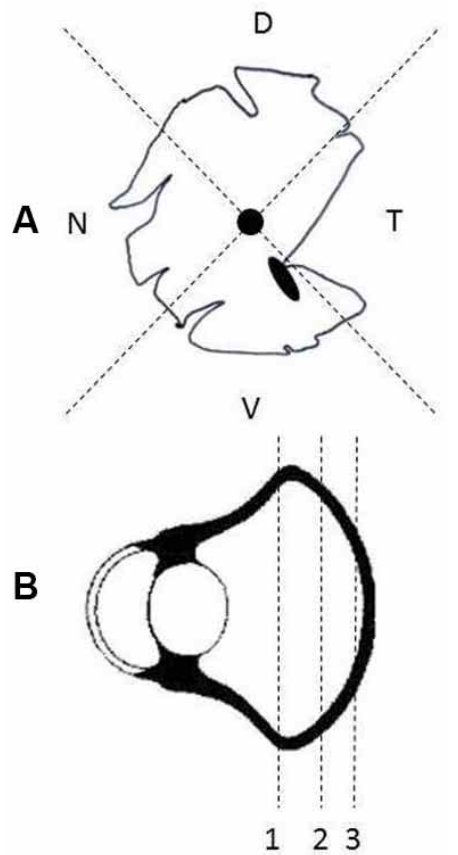

Fig. 1. A. Four retinal fields (Dorsal; Temporal; Ventral; Nasal) in Strigidae retinal fundus. Optic disk (black round shape); pecten (black oval shape). B. Scheme of Strigidae eyeball: retinal radial section at three levels (1: ora serrata, 2: half distance between levels 1 and 3, 3: optic disc).
These parameters enabled to distinguish RGCs from glial cells which have small, slightly elongated cell body, reduced or not detectable cytoplasm and negative to Nissl staining (Fig. 2). Nikon ECLIPSE Ni microscope, connected to Nikon-Digital.Sight DS-U1 digital image acquisition system, was used to analyze each slice from the three levels. The number of RGCs $/ \mathrm{mm}^{2}$ (cell density) and the soma size of RGCs were obtained analyzing a reference area $\left(0.06 \mathrm{~mm}^{2}\right)$ into the thickness of the RGCs layer by a NIS-Elements Basic Research software, at a magnification of 20x. The cell density in each reference area was reported and the RGCs were classified on the basis of four different range of median soma area $\left(<50 \mathrm{~mm}^{2}, 50-100 \mathrm{~mm}^{2}, 100-150 \mathrm{~mm}^{2}\right.$ and $\left.>150 \mathrm{~mm}^{2}\right)$. The results are given without corrections for shrinkage.

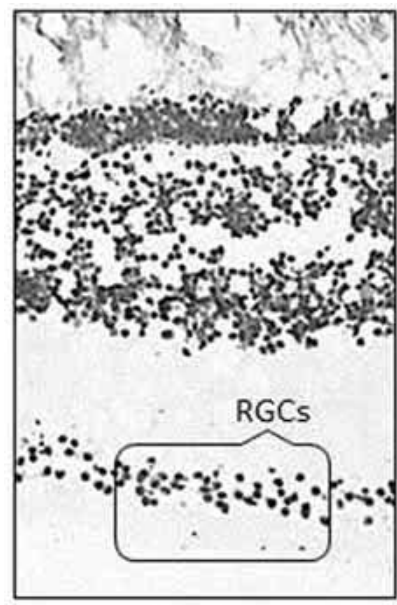

little owl

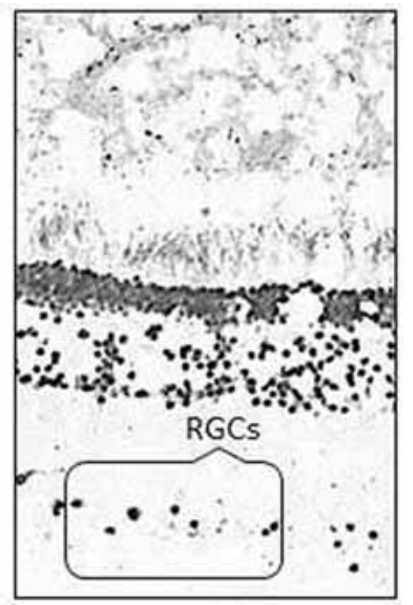

eared owl
Fig. 2. Radial section of little owl and eared owl retina: the RGCs are highlighted in the insert (Nissl method).

\section{RESULTS}

The Figure 3 shows the RGCs density related to the retinal fields $(\mathrm{D}, \mathrm{T}, \mathrm{V}, \mathrm{N})$ and to the three level section. The lowest values of density in all the retinal fields are found in the retina of eared owl. In all the raptors the highest RGCs number $/ \mathrm{mm}^{2}$ is detectable in the ventral retinal field, even if it is not homogeneously distributed among section levels: Indeed, the little owl shows the highest cell density at the level of optic disc (level 3) while in the other raptors the highest density is highlighted at the level of the ora serrata (level 1).

The Figure 4 shows the RGCs density in temporonasal and dorso-ventral directions to identify specialized retinal vision areas. 

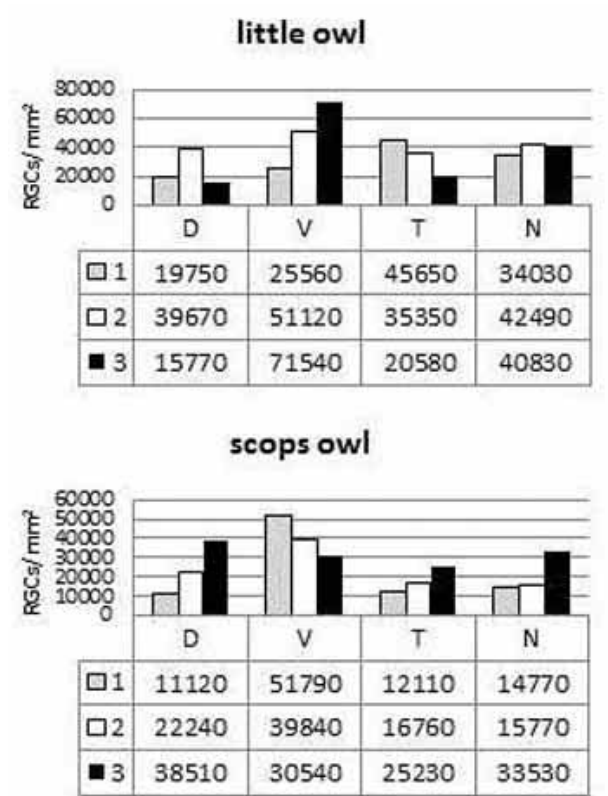
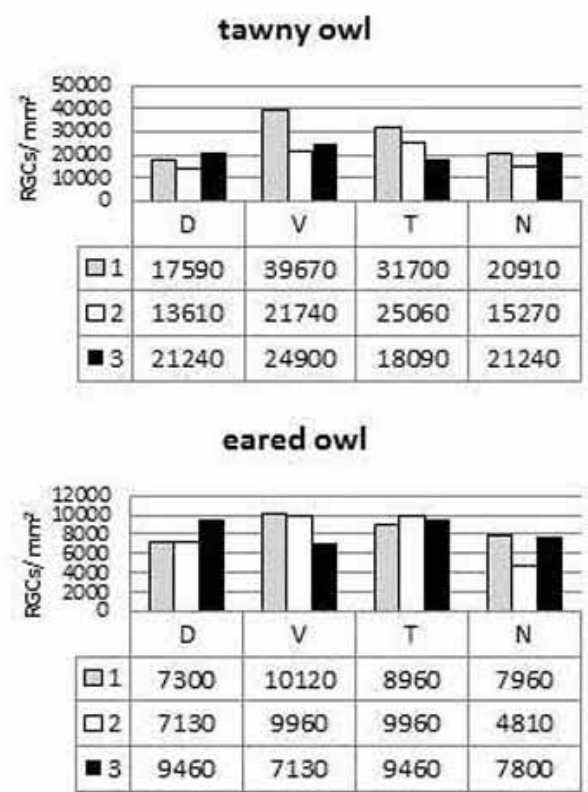

The study of the RGCs density in the temporo-nasal direction in the retina of the little owl points out lower values toward central temporal field (T3). In the retina of tawny owl this decrease reaches also external/ intermediate nasal fields (N1/ N2). A Gaussian trend, with higher values in the central retinal fields $(\mathrm{T} 3 / \mathrm{N} 3)$ and lower values to the peripheral fields (T1/N1) is evidenced in the retina of the scops owl. The RGCs density in the eared owl retina is rather steady with a reduction only in the intermediate nasal field (N2).

Fig. 3. RGCs density (number of cells $/ \mathrm{mm}^{2}$ ) in Strigidae raptors (D, T, V, N: retinal fields; 1, 2, 3: section levels).

Table I. Percentage distribution of the RGCs according to range of medium soma area in each retinal fields (D,V,T,N) and section level $(1,2,3)$ in Strigidae raptors.

\begin{tabular}{|c|c|c|c|c|c|c|c|c|c|}
\hline Little owl & $\begin{array}{l}<50 \\
m \mu^{2}\end{array}$ & $\begin{array}{c}50-100 \\
m \mu^{2}\end{array}$ & $\begin{array}{c}100-150 \\
m \mu^{2}\end{array}$ & $\begin{array}{l}>150 \\
m \mu^{2}\end{array}$ & $\begin{array}{c}\text { Tawny } \\
\text { owl }\end{array}$ & $\begin{array}{l}<50 \\
m \mu^{2}\end{array}$ & $\begin{array}{c}50-100 \\
m \mu^{2}\end{array}$ & $\begin{array}{c}100-150 \\
m \mu^{2}\end{array}$ & $\begin{array}{c}>150 \\
m \mu^{2}\end{array}$ \\
\hline D1 & 8 & 87 & 5 & & $D 1$ & & 78 & 17 & 5 \\
\hline$V 1$ & 60 & 38 & 2 & & $V 1$ & & 82 & 16 & 2 \\
\hline$T 1$ & 9 & 90 & 1 & & $T 1$ & & 79 & 17 & 4 \\
\hline N1 & 4 & 94 & 2 & & N1 & & 86 & 12 & 3 \\
\hline D2 & 21 & 75 & 4 & & D2 & & 72 & 23 & 5 \\
\hline$V 2$ & 15 & 83 & 2 & & $V 2$ & & 81 & 14 & 5 \\
\hline$T 2$ & 4 & 90 & 6 & & $T 2$ & & 70 & 25 & 5 \\
\hline$N 2$ & 12 & 87 & 1 & & N2 & & 73 & 16 & 11 \\
\hline D3 & 7 & 87 & 6 & & D3 & & 69 & 23 & 8 \\
\hline$V 3$ & 17 & 81 & 2 & & $V 3$ & & 87 & 9 & 4 \\
\hline$T 3$ & 4 & 87 & 9 & & $T 3$ & & 77 & 19 & 4 \\
\hline N3 & 4 & 92 & 4 & & N3 & & 59 & 35 & 6 \\
\hline $\begin{array}{c}\text { Scops } \\
\text { owl } \\
\text { D1 }\end{array}$ & $\begin{array}{l}<50 \\
m \mu^{2}\end{array}$ & $\begin{array}{c}50-100 \\
\boldsymbol{m} \boldsymbol{\mu}^{2} \\
72\end{array}$ & $\begin{array}{c}100-150 \\
m \boldsymbol{\mu}^{2} \\
24\end{array}$ & $\begin{array}{c}>150 \\
m \mu^{2}\end{array}$ & $\begin{array}{c}\text { Eared owl } \\
\text { D1 }\end{array}$ & $\begin{array}{l}<50 \\
m \mu^{2}\end{array}$ & $\begin{array}{c}50-100 \\
\boldsymbol{m} \boldsymbol{\mu}^{2} \\
75\end{array}$ & $\begin{array}{c}100-150 \\
m \mu^{2} \\
25\end{array}$ & $\begin{array}{r}>150 \\
m \mu^{2}\end{array}$ \\
\hline$V 1$ & & 98 & 2 & & $V 1$ & & 72 & 16 & 12 \\
\hline$T 1$ & & 85 & 11 & & $T 1$ & & 91 & 9 & \\
\hline N1 & 77 & 20 & 3 & & N1 & & 67 & 21 & 12 \\
\hline D2 & & 80 & 19 & & D2 & & 53 & 35 & 5 \\
\hline$V 2$ & & 99 & 1 & & $V 2$ & & 78 & 17 & \\
\hline$T 2$ & & 84 & 16 & & $T 2$ & & 82 & 18 & \\
\hline N2 & & 100 & & & N2 & & 100 & & \\
\hline D3 & & 99 & 1 & & D3 & & 84 & 16 & \\
\hline$V 3$ & 89 & 9 & 2 & & $V 3$ & & 30 & 30 & 40 \\
\hline$T 3$ & & 94 & 6 & & $T 3$ & & 72 & 19 & 9 \\
\hline N3 & & 98 & 2 & & N3 & & 49 & 28 & 23 \\
\hline
\end{tabular}



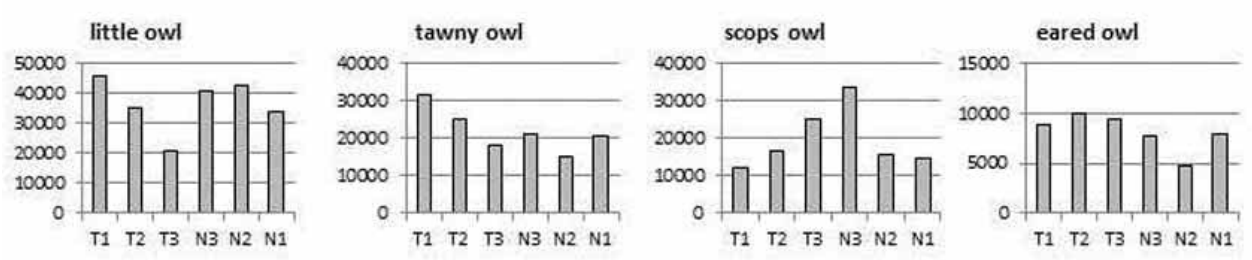

Dorso-ventral direction
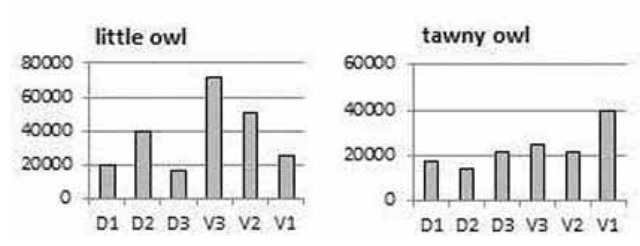
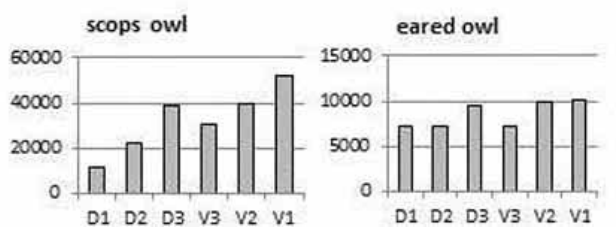

Fig. 4. RGCs density in Temporo-nasal and Dorsoventral directions in Strigidae raptors. (T1: external temporal; T2: intermediate temporal; T3: central temporal; N3: central nasal; N2: intermediate nasal; N1: external nasal; D1: external dorsal; D2: intermediate dorsal; D3: central dorsal; V3: central ventral; V2: intermediate ventral; V1: external ventral).
Regarding the dorso-ventral direction, in all the Strigidae the ventral retinal fields show an higher density than the dorsal fields. In the little owl retina the higher values are found in the central peripheral field (V3) while in the tawny owl and the scops owl this parameter is highlighted in the ventral peripheral fields (V1). The RGCs density in the eared owl retina is almost steady in dorso-ventral direction too.

The percentage of distribution of the RGCs according to four different ranges of median soma area $\left(<50 \mathrm{~mm}^{2}, 50\right.$ $100 \mathrm{~mm}^{2}, 100-150 \mathrm{~mm}^{2}$ and $>150 \mathrm{~mm}^{2}$ ) in each retinal field and section level are showed in Table I. The RGCs with < $50 \mathrm{~mm} 2$ of median soma area are only recorded in the retinal fields at each section level in the little owl and in the peripheral nasal field (N1) and central ventral field (V3) in the scops owl retina. In all the Strigidae analyzed the most represented population of RGCs in all the section levels and retinal fields is in the range of $50-100 \mathrm{~mm}^{2}$ of median soma area (ranging from $20 \%$ to $100 \%$ ) with the exception of those fields where the RGCs with $<50 \mathrm{~mm}^{2}$ of median soma are recorded. The percentage of the RGCs in the range of $100-150 \mathrm{~mm}^{2}$ of median soma area is high in the tawny owl and in the eared owl retinas (ranging from $9 \%$ to $35 \%$ ). Conversely in the little owl retina this range does not exceed $9 \%$ in all the retinal fields and in the scops owl retina reaches $24 \%$ in D1. The largest RGCs (> $150 \mathrm{~mm}^{2}$ ) lack in the little owl retina and only the eared owl retina shows an high percentage of these cells, particularly in the ventral field, near the optic disc (V3) where this value reached $40 \%$. The largest RGCs are the least represented in the retinas of tawny owl and scops owl where the percentage is lower than $11 \%$.

\section{DISCUSSION}

Many authors reported on the number and distribution of RGCs in Strigiformes raptors which differ with activity patterns and habitat (Oehme; Bravo \& Pettigrew, 1981; Güntürkün, 2000; Lisney et al.): all these studies are carried out using retinal wholemounts. Since in the highest density areas of avian retinas (Bravo \& Pettigrew) the RGCs become smaller and distributed into multiple sublayers, as also reported previously (Coli et al.), the authors refer to the study of RGCs density by radial retinal sections to also identify the deeper RGCs and to distinguish them from the displaced amacrine cells.

The evaluation of RGCs density in temporo-nasal and dorso-ventral directions points out retinal areas with high RGCs density that might be justified by the presence of specialized areas like fovea or visual streak. In little owl, tawny owl and eared owl retinas the localization of a temporal fovea, as reported by Lisney et al. in nine species of owls, might be linked with the high density found in the temporal field. While in eared owl retina the RGCs distribution is quite steady, in the other two raptors a decrease in temporal fundus oculi (T3) is evident. In scops owl retina

Table II. Predatory behavior of the four Strigidae raptors.

\begin{tabular}{lll}
\hline Common name & Species & Predatorybehavior \\
\hline Little owl & Athene noctua & $\begin{array}{l}\text { Eats small vertebrates, predominantly in open spaces, hunting on the ground after a short } \\
\text { flight }\end{array}$ \\
Tawny owl & Strix aluco & Eats small and medium sized mammals, amphibians and birds, hunting the prey quickly \\
Scops owl & Otus scops & Eats insects, reptiles, small mammals and birds, hunting from perches in semi-open landscapes \\
Eared owl & Asio otus & Eats rodents, small mammals and birds, hunting over open country by night.
\end{tabular}


it is not possible to localize a temporal fovea, as in the other raptors, because a high RGCs density is identified in temporal and nasal fundus oculi (T3 and N3). A high RGCs density in nasal fields related to the presence of a streak in the nasal direction is pointed out in little owl retina.

A particular outline of a radial visual streak better detectable ventrally, as reported by Lisney et al. in other Strigidae (barred owl, northern saw-whet owl) is also identified by the authors in the ventral fields of the four raptors, even if with different distribution according to the section level. With the exception of little owl, where the most RGCs are in ventral fundus oculi (V3), in the other three raptors the outline of the visual streak reaches the peripheral ventral fields (V1). As reported by Lisney et al. an increase of RGCs number in ventral fields might be responsible for a greater image projection on the visual cortex. The particular outline of the radial visual streak might also be correlated with the predatory behavior of the four Strigidae analyzed. As summarized in Table II, these typical owls are generally nocturnal and spend much of the day roosting. Their preys are small and generally moves on the ground, so it is necessary that the best visual acuity be linked in the ventral visual fields. Moreover, in all four analyzed Strigidae a tapetum lucidum in the dorsal fields at the opening of the eyeballs is visible, thus confirming its role in the amplifying the light in the dark, as reported in a previous study (Coli et al.).

The study of percentage distribution of RGCs according to the ranges of medium soma area points out that the most represented RGCs population $\left(50-100 \mathrm{~mm}^{2}\right.$ of median soma area) is localized in the areas of greater visual acuity where the RGCs density increases, thus confirming the bibliographic data (Ikushima et al., 1986). Considering the close correlation between the cell soma size and their morphological type [Ikushima et al. in quail retina; Binggeli \& Paule (1969) in pigeon retin] the cells most represented in the retina of the Strigidae studied, and related to the medium-large range, might be definable as the alpha cells in the classification of cat retinal ganglion cells (Boycott \& Wässle, 1974). Our data suggests extending the RGCs studies to other families of the order of Strigiformes with the same research procedure.

\section{ACKNOWLEDGMENTS}

We are grateful to Renato Ceccherelli, DVM, Health Director of the Center of Recovery Seabirds and Waterfowl (Lipu, Livorno, Italy) for his assistance and collaboration in the sample collection.
COLI, A.; STORNELLI, M. R.; LENZI, C. \& GIANNESSI, E. Células ganglionares de la retina en aves rapaces strigidae: distribución y morfometría. Int. J. Morphol., 36(4):1175-1179, 2018.

RESUMEN: Se estudió la morfometría y la distribución topográfica de las células ganglionares de la retina (CGR) en cuatro aves rapaces nocturnas del orden de los Strigiformes, familia Strigidae: búho pequeño, mochuelo, autillo, y cárabo. Con el objetivo de definir las áreas de visión retiniana especializadas (fóvea y campo visual), se registró el número de CGRs $/ \mathrm{mm}^{2}$ y el tamaño del soma en los cuatro campos retinianos (dorsal, ventral, temporal y nasal), mediante análisis histológico de las secciones radiales de la retina. Se identificó una fóvea temporal en mochuelo, búho leonado y búho pequeño, mientras que en el búho real, esta área visual se localizó cerca del fondo de ojo. Se observó un campo radial visual dirigido ventralmente en las retinas de las cuatro aves rapaces, con diferentes formas según su extensión. Se relacionaron los datos obtenidos con el comportamiento predatorio de aves rapaces nocturnas en su hábitat.

PALABRAS CLAVE: Células ganglionares de la retina; Morfometría; Distribución topográfica; Aves rapaces nocturnas; Strigidae.

\section{REFERENCES}

Binggeli, R. L. \& Paule, W. J. The pigeon retina: quantitative aspects of the optic nerve and ganglion cell layer. J. Comp. Neurol., 137(1):1-18, 1969.

Boycott, B. B. \& Wässle, H. The morphological types of ganglion cells of the domestic cat's retina. J. Physiol., 240(2):397-419, 1974.

Bravo, H. \& Pettigrew, J. D. The distribution of neurons projecting from the retina and visual cortex to the thalamus and tectum opticum of the barn owl, Tyto alba, and the burrowing owl, Speotyto cunicularia. J. Comp. Neurol., 199(3):419-44, 1981.

Coli, A.; Stornelli, M. R.; Barsotti, G.; Lenzi, C.; Bogi, F. \& Giannessi, E. Number and topographical distribution of retinal ganglion cells in diurnal and nocturnal raptors. Int. J. Morphol., 36(3):955-61, 2018.

Cunningham, J. G. Manuale di Fisiologia Veterinaria. $3^{\text {rd }}$ ed. Rome, Antonio Delfino Editore, 2006.

Duke-Elder, S. The emergence of vision in the animal world. Ann. R. Coll. Surg. Engl., 23(1):1-24,1958.

Gutiérrez-Ibáñez, C.; Iwaniuk, A. N.; Lisney, T. J. \& Wylie, D. R. Comparative study of visual pathways in owls (Aves: Strigiformes). Brain Behav. Evol., 81(1):27-39, 2013.

Ikushima, M.; Watanabe, M. \& Ito, H. Distribution and morphology of retinal ganglion cells in the Japanese quail. Brain Res., 376(2):320-34, 1986.

Jones, M. P.; Pierce, K. E. Jr. \& Ward, D. Avian vision: A review of form and function with special consideration to birds of prey. J. Exot. Pet Med., 16(2):69-87, 2007

Lisney, T. J.; Iwaniuk, A. N.; Bandet, M. V. \& Wylie, D. R. Eye shape and retinal topography in owls (Aves: Strigiformes). Brain Behav. Evol., 79(4):218-36, 2012.

Oehme, H. Vergleichend-histologische Untersuchungen an der Retina von Eulen. Berlin, Humboldt-Univ., 1961.

Corresponding author:

Alessandra Coli

Department of Veterinary Sciences

University of Pisa, Viale delle Piagge, 2

56122 Pisa

ITALY

Received: 27-06-2018

Accepted: 22-08-2018

Email: alessandra.coli@unipi.it 